\title{
ANAEROBIC BIOTRANSFORMATION OF POLYCHLORINATED METHANE AND ETHENE UNDER VARIOUS REDOX CONDITIONS
}

\author{
Ruey-an Doong ${ }^{1^{*}}$, Shian-chee $\mathrm{Wu}^{2}$ and Tsu-feng Chen ${ }^{1}$
}

1: Department of Nuclear Science, National Tsing Hua University, Hsinchu, 30043, Taiwan, R.O.C.

2: Graduate Institute of Environmental Engineering, National Taiwan University, Taipei, 10670, Taiwan, R.O.C.

(Received in Germany 18 September 1995; accepted 6 November 1995)

\begin{abstract}
Two sets of batch-type experiments with different concentrations of acetate as the auxiliary substrate was performed under various redox conditions to evaluate the effects of the redox potential of the environment and substrate concentration on the biotransformation of carbon tetrachloride (CT) and tetrachloroethylene (PCE). Experimental results indicated that the redox potential of the environment is a more influential environmental factor than the substrate concentration in affecting the biotransformability of the chlorinated hydrocarbons. Disappearances of 20 to $62 \%$ and 22 to $99.9 \%$ of the original concentrations of PCE and CT, respectively, were observed with the redox potentials of the microcosms ranging from 188 to $-263 \mathrm{mV}$. The threshold values of -60 and $70 \mathrm{mV}$ were also identified for the obvious biotransformation (> 30\%) of PCE and CT, respectively. Substrate concentration effect was emphasized only when the redox potential of the microcosms was below the threshold value. The strong-electron-acceptor-inhibition hypothesis based on the thermodynamic rules provides an explanation for the difference of the biotransformability between PCE and CT under different redox potential conditions. A lower redox potential provided a relatively higher electron activity, thereby facilitating dechlorination reaction more readily. A higher substrate concentration produced more biomass than a lower substrate concentration. Results in this study have provided further insight into the foundation of in-situ bioremediation practices Furthermore, more accurately controlling the redox potential of the environment would yield a higher remediation efficiency for the groundwater contaminated with chlorinated hydrocarbons.
\end{abstract}




\section{INTRODUCTION}

The possibilities for degrading hazardous contaminants in situ by stimulating the microflora with the addition of carbon and energy sources and trace mineral elements have received increasing interest in recent years. (Anderson et al., 1993; Fan and Scow, 1993; Hopkins et al., 1993; Rainwater et al., 1993; Doong and $\mathrm{Wu}, 1995 \mathrm{a}$ ). Enhanced in-situ biodegradation of highly chlorinated hydrocarbons is of particular interest owing to their persistences and reported health risks (Federal Register, 1989). Recent studies have demonstrated that heavily chlorinated hydrocarbons can be fortuitously biotransformed under denitrification (Criddle et al., 1990; Semprini et al., 1992; Tatara et al., 1993; Bybas et al., 1995), sulfate-reducing (Bagley and Gossett, 1990; DiStefano et al., 1992; Doong and $\mathrm{Wu}, 1995 \mathrm{~b}$ ), and methanogenic conditions (Bouwer and Wright, 1988; Gibson and Sewell, 1992; DeBruin et al., 1992) into less chlorinated compounds that are more biodegradable. Rates of transformation are generally faster under more reducing conditions.

In addition, the biotransformability of chlorinated hydrocarbons under the existence of different electron acceptors was also investigated in column or batch experiments (Bouwer and Wright, 1988; Criddle et al., 1990). Conditions in which weaker terminal electron acceptors existed were more conducive to higher rates of reductive dechlorination of chlorinated hydrocarbons. Sequential biofilm zones of aerobic, denitrification, and sulfate-reducing developments within a biofilm column showed that the redox potential of the environment was also an important environmental factor influencing the biotransformation of chlorinated hydrocarbons (Cobb and Bouwer,1991). Esaac and Matsumura (1980) reported that significant reductive dechlorination occurred only when the redox potential of the environment was lower than $350 \mathrm{mV}$. Parsons et al. (1985) depicted that the dechlorination of chlorinated hydrocarbons could take place when the oxidation-reduction potential(ORP) of the sealed microcosms was below the value of $300 \mathrm{mV}$. However, the effective redox potential might be different for various compounds. Furthermore, Assaf-Anid et al.(1994) demonstrated that the pseudo-firstorder rate constant of carbon tetrachloride disappearance increased with a decreasing redox potential; in addition, the linear correlation between $\ln \mathrm{K}_{1}$ and measured redox potential was established.

The interpretation of redox potentials obtained from electrode measurements in natural water is subject to numerous complications, despite the fact that the measured redox potential is useful as an indicator of oxidation-reduction conditions in the environment (Grundl and Macalady, 1989; Peiffer et al., 1992). Also, the redox condition of the environment is markedly influenced by the supply and reactivity of electron donors (auxiliary substrate). Moreover, their roles on the biotransformation of chlorinated hydrocarbons have not yet been well understood. In this study, two sets of experiments with different compositions of chlorinated hydrocarbons, the mixed contaminants and the single contaminant systems, were performed in a variety of concentrations of substrate and redox potentials to evaluate the effects of the environmental factors on the biotransformation of heavily chlorinated hydrocarbons. A strongelectron-acceptor-inhibition hypothesis based on the thermodynamic rules was also proposed to interpret the discrepancy of the biotransformation of chlorinated hydrocarbons under various redox potentials. 


\section{BACKGROUND AND STRONG-ELECTRON-ACCEPTOR INHIBITION HYPOTHESIS}

Measured redox potential is an index of the oxidation-reduction state of the environment. In an aqueous solution, oxidation-reduction state of the solution can be expressed in terms of the logarithm of the electron activity of the dominating redox couple:

$$
\mathrm{pe}=-\log \{\mathrm{e}\}=\mathrm{pe}^{\mathrm{o}}-\frac{\mathrm{RT}}{\mathrm{nF}} \log \frac{\text { (reduction }\}}{\text { \{oxidation }\}}
$$

where pe represents the relative tendency of a solution to accept or donate electrons. In an environmental system, the pe and the ORP can be related to each other by equation 2 :

$$
p e=\frac{F}{2.303 R T} E_{H}
$$

where $\mathrm{F}$ is the Faraday constant, $\mathrm{R}$ is the universal gas constant, $\mathrm{T}$ is the absolute temperature, and $\mathrm{E}_{\mathrm{H}}$ is the equilibrium redox potential on the hydrogen scale. A high pe value indicates a relatively high oxidizing intensity (to accept electrons).

Only a few elements, e.g., carbon (C), nitrogen $(\mathrm{N})$, oxygen (O), iron (Fe) and sulfur (S), are predominant participants in natural aquatic redox processes. Microorganisms preferentially utilize the electron acceptor with the highest pe value first which provides the maximum free energy during respiration. The redox potentials of $+810,+750,-220$, and $-240 \mathrm{mV}$ in an environmental system correspond to the environment dominated sequentially by the redox couple of $\mathrm{O}_{2} / \mathrm{H}_{2} \mathrm{O}, \mathrm{NO}_{3}{ }^{-} / \mathrm{N}_{2}, \mathrm{SO}_{4}{ }^{2 \cdot}$ $/ \mathrm{H}_{2} \mathrm{~S}$ or $\mathrm{CO}_{2} / \mathrm{CH}_{4}$, respectively. Also, chlorinated hydrocarbons can function as electron acceptors competing with electrons derived from an organic substrate with other electron acceptors in the microbial environment. Table 1 indicates that the standard redox potential of chlorinated hydrocarbons (PCE/TCE, CT/CF) is lower than $\mathrm{O}_{2} / \mathrm{H}_{2} \mathrm{O}$ and $\mathrm{NO}_{3}{ }^{-} / \mathrm{N}_{2}$, but is higher than $\mathrm{NO}_{3}{ }^{-} / \mathrm{NO}_{2}{ }^{-}, \mathrm{SO}_{4}{ }^{2-} / \mathrm{H}_{2} \mathrm{~S}$, and $\mathrm{CO}_{2} / \mathrm{CH}_{4}$ This occurrence implies that chlorinated hydrocarbons may obtain an electron to proceed with reductive dechlorination under denitrification, sulfate-reducing, and methanogenic conditions (low redox potential). On the other hand, dechlorination is inhibited by strong electron acceptors under the oxidizing environment. For instance, in the aerobic and denitrification environments, the dominant redox reactions of the environment are :

$$
\begin{array}{ll}
1 / 4 \mathrm{O}_{2}+\mathrm{H}^{+}+e^{-}=1 / 2 \mathrm{H}_{2} \mathrm{O} & \mathrm{pe}^{\mathrm{o}}=20.75 \\
1 / 2 \mathrm{NO}_{3}^{-}+\mathrm{H}^{+}+e^{-}=1 / 2 \mathrm{NO}_{2}^{-}+1 / 2 \mathrm{H}_{2} \mathrm{O} & \mathrm{pe}^{\mathrm{o}}=7.15
\end{array}
$$

As chlorinated hydrocarbons are added into the system, the reductive dechlorination reactions having occurred are : 


$$
\begin{array}{ll}
1 / 2 \mathrm{CCl}_{4}+1 / 2 \mathrm{H}^{+}+e^{-}=1 / 2 \mathrm{CHCl}_{3}+1 / 2 \mathrm{Cl}^{-} & \mathrm{pe}^{0}=11.42 \\
1 / 2 \mathrm{C}_{2} \mathrm{Cl}_{4}+1 / 2 \mathrm{H}^{+}+e^{-}=1 / 2 \mathrm{C}_{2} \mathrm{HCl}_{3}+1 / 2 \mathrm{Cl}^{-} & \mathrm{pe}^{0}=9.71
\end{array}
$$

Then, by Nerst equation, the concentration ratios of CF/CT and TCE/PCE are estimated to be $10^{.77}$ and $10^{-135}$ for aerobic and $10^{378}$ and $10^{320}$ for denitrification, respectively, by assuming that $\left[\mathrm{H}^{+}\right]=10^{-7}$ $\mathrm{M},\left[\mathrm{Cl}^{-}\right]=10^{-3} \mathrm{M},\left[\mathrm{O}_{2}\right]=10^{-0.7}\left(8.3 \mathrm{mg} / \mathrm{L}\right.$ ), and $\left[\mathrm{NO}_{3}{ }^{-}\right]=10 \mathrm{mg} / \mathrm{L}$ (Vogel et al.,1987; Cobb and Bouwer, 1991). This calculation demonstrates that the dechlorination of the chlorinated hydrocarbons could be totally depressed under a high redox potential condition and certain threshold values of pe. Such an occurrence is referred to here as the strong-electron-acceptor inhibition phenomenon. Also, we can infer that $\mathrm{CT}$ is more susceptible for biotransformation than PCE for its higher reduction potential

Table 1. The standard half redox potentials $\left(\mathrm{E}_{\mathrm{H}}^{\circ}\right)$ of chlorinated hydrocarbons and the primary

\begin{tabular}{|c|c|c|c|}
\hline $\begin{array}{l}\text { electron } \\
\text { acceptor }\end{array}$ & redox reactions & $\begin{array}{r}\mathrm{pe}^{\mathrm{o}}{ }_{\mathrm{w}} \\
(\mathrm{pH}=7)\end{array}$ & $\begin{array}{l}\mathrm{E}_{\mathrm{H}}^{\circ} \ddagger \\
(\mathrm{mV})\end{array}$ \\
\hline $\mathrm{O}_{2}$ & $\mathrm{O}_{2}(\mathrm{~g})+4 \mathrm{H}^{+}+4 e=2 \mathrm{H}_{2} \mathrm{O}$ & +13.75 & 813 \\
\hline $\mathrm{NO}_{3}^{-}$ & $2 \mathrm{NO}_{3}^{-}+12 \mathrm{H}^{+}+10 e=\mathrm{N}_{2}(\mathrm{~g})+6 \mathrm{H}_{2} \mathrm{O}$ & +12.65 & 749 \\
\hline $\mathrm{CT}$ & $\mathrm{CCl}_{4}+\mathrm{H}^{+}+2 e=\mathrm{CHCl}_{3}+\mathrm{Cl}^{-}$ & +11.42 & 676 \\
\hline PCE & $\mathrm{CCl}_{2} \mathrm{CCl}_{2}+\mathrm{H}^{+}+2 e=\mathrm{CHClCCl}_{2}+\mathrm{Cl}^{-}$ & +9.71 & 574 \\
\hline TCA & $\mathrm{CH}_{3} \mathrm{CCl}_{3}+\mathrm{H}^{+}+2 e=\mathrm{CH}_{2} \mathrm{CHCl}_{2}+\mathrm{Cl}^{-}$ & +9.48 & 561 \\
\hline $\mathrm{NO}_{3}^{-}$ & $\mathrm{NO}_{3}^{-}+2 \mathrm{H}^{+}+2 e=\mathrm{NO}_{2}^{-}+\mathrm{H}_{2} \mathrm{O}$ & +7.15 & 423 \\
\hline $\mathrm{NO}_{3}^{-}$ & $\mathrm{NO}_{3}^{-}+10 \mathrm{H}^{+}+8 e=\mathrm{NH}_{4}^{+}+3 \mathrm{H}_{2} \mathrm{O}$ & +6.15 & 364 \\
\hline $\mathrm{Fe}(\mathrm{III})$ & $\mathrm{FeOOH}(\mathrm{s})+\mathrm{HCO}_{3}^{-}+2 \mathrm{H}^{+}+e=\mathrm{FeCO}_{3}(\mathrm{~s})+2 \mathrm{H}_{2} \mathrm{O}$ & -0.80 & -47 \\
\hline $\mathrm{SO}_{4}^{2-}$ & $\mathrm{SO}_{4}^{2-}+10 \mathrm{H}^{+}+8 e=\mathrm{H}_{2} \mathrm{~S}(\mathrm{~g})+4 \mathrm{H}_{2} \mathrm{O}$ & -3.50 & -207 \\
\hline $\mathrm{SO}_{4}^{2-}$ & $\mathrm{SO}_{4}^{2-}+9 \mathrm{H}^{+}+8 e=\mathrm{HS}^{-}+4 \mathrm{H}_{2} \mathrm{O}$ & -3.75 & -222 \\
\hline $\mathrm{CO}_{2}$ & $\mathrm{CO}_{2}(\mathrm{~g})+8 \mathrm{H}^{+}+8 e=\mathrm{CH}_{4}+2 \mathrm{H}_{2} \mathrm{O}$ & -4.13 & -244 \\
\hline
\end{tabular}
electron acceptors in an aquatic environment.

$\dagger: \mathrm{peo}^{\circ}$ is the hypothetical electron activity $(-\log \{\mathrm{e}\})$ at the standard state; ${ }^{\mathrm{peo}}{ }_{\mathrm{w}}$ is the activity at $\mathrm{pH}$ $=7$.

$\ddagger$ at $25^{\circ} \mathrm{C}, \mathrm{p}^{\circ}{ }_{\mathrm{w}}=16.9 \mathrm{E}_{\mathrm{H}}^{\circ}$ 
MATERIALS AND METHODS

Reagents and materials. The chlorinated hydrocarbons used in this study, carbon tetrachloride (CT) (99.8\%, GC grade), tetrachloroethylene (PCE) (99.8\%, GC grade), and chloroform (CF) $(99.8 \%$, GC grade) were purchased from Merck Co., Darmstadt, Germany. Trichloroethylene (TCE) $(99.8 \%$, GC grade) was obtained from Ishizu Pharmaceutical Co., Osaka, Japan. The fluorescing stain, 4'6diamidino-2-phenylindole (DAPI), was purchased from Aldrich Chemical Co., Inc., Milwaukee, Wisco., U. S. A.

Anaerobic mix-culture consortia was obtained from the anaerobic digester sludge of the Taiwan Sugar Corporation wastewater treatment facility (Hsinchu, Taiwan). It was then incubated at $35^{\circ} \mathrm{C}$ in a 2 liter glass flask with a magnetic stirrer under anaerobic condition. $200 \mathrm{~mL}$ of the substrate solution consisting of $15000 \mathrm{mg} / \mathrm{L}$ acetic acid, $5000 \mathrm{mg} / \mathrm{L}$ propionic acid, vitamin, reducing agents $\left(\mathrm{Na}_{2} \mathrm{~S}\right.$; $\mathrm{FeCl}_{2}$ ), and mineral growth factors were daily added into the inoculum culture to maintain adequate microbial activities. The supplement of auxiliary substrate solution was curtailed 2 to 3 days before the beginning of each experiment to exhaust the residual carbon sources in the anaerobic culture.

Biotransformation batch studies. Two sets of biotransformation experiments were conducted under anaerobic condition. The first set of experiments was conducted by delivering the mixture of $\mathrm{CT}$ and PCE into the same serum bottles (mixed contaminants system).

$45 \mathrm{~mL}$ of the reducing media containing (per liter of deionized water) $1800 \mathrm{mg} / \mathrm{L} \mathrm{of} \mathrm{MgCl}_{2} \cdot 6 \mathrm{H}_{2} \mathrm{O}$, $1300 \mathrm{mg} / \mathrm{L}$ of KCl, $500 \mathrm{mg} / \mathrm{L}$ of $\left(\mathrm{NH}_{4}\right)_{2} \mathrm{HPO}_{4}, 250 \mathrm{mg} / \mathrm{L}$ of $\mathrm{CaCl}_{2} \cdot 2 \mathrm{H}_{2} \mathrm{O}, 400 \mathrm{mg} / \mathrm{L}$ of $\mathrm{NH}_{4} \mathrm{Cl}, 500$ $\mathrm{mg} / \mathrm{L}$ of $\mathrm{Na}_{2} \mathrm{~S} \cdot 9 \mathrm{H}_{2} \mathrm{O}, 370 \mathrm{mg} / \mathrm{L}$ of $\mathrm{FeCl}_{2} \cdot 4 \mathrm{H}_{2} \mathrm{O}, 15 \mathrm{~mL}$ of a trace element solution and $1 \mathrm{~mL}$ of vitamin solution (Owen et al., 1979; Egli et al., 1988), were added in sterilized $60 \mathrm{~mL}$ serum bottles. Serum bottles were purged with nitrogen gas and $1 \mathrm{~mL}$ aliquot of the seeding culture was introduced into each bottle. Bottles were sealed with Teflon-lined rubber septa and aluminum crimp caps (Wheaton Co., N.J.) immediately after the aqueous solutions of chlorinated hydrocarbons and the auxiliary substrate were added. Solution of sodium acetate used as the auxiliary substrate was introduced into the serum bottles to give a concentration of either 10 or $30 \mathrm{mg} / \mathrm{L}$. The chlorinated hydrocarbons mixture was added through the septum with a gas-tight syringe to achieve an initial concentration of either 100 or $500 \mu \mathrm{g} / \mathrm{L}$. The total volume of the liquid phase was $50 \mathrm{~mL}$, resulting in $10 \mathrm{~mL}$ for headspace analysis. Systems with various redox potentials were produced by taking off the purge devices at different times; the redox potentials were determined with an ORP electrode.

In the second set of experiments, all procedures were the same as those of the mixed contaminants system. However, only one of the chlorinated hydrocarbons was added in each serum bottle (a single contaminant system). 
Blank controls without substrate nor seedings were performed by following the procedure described above, but $10 \mathrm{mg} / \mathrm{L}$ of $\mathrm{HgCl}_{2}$ was added as microbial inhibitors. All serum bottles were wrapped with aluminum foil to avoid photodecomposition and incubated in dark at $35^{\circ} \mathrm{C}$. Chlorinated hydrocarbons were monitored periodically by injecting the headspace gas into a gas chromatograph and bottles were discarded thereafter.

Analytical Methods. The concentrations of chlorinated compounds in the headspace of the test bottles were monitored by drawing $5 \mu \mathrm{L}$ of gas phase and $10 \mu \mathrm{L}$ gas in the headspace of the bottle with the internal standard (bromoform) with a $25 \mu \mathrm{L}$ gas-tight syringe (Hamilton, cat. No. 1702N, USA) and injecting the mixture into a gas chromatograph (model 5890A, Hewlett-Packard, Avondale, Pa., USA) equipped with an electron capture detector (ECD) and a 3392A integrator. A DB-624 fused-silica megabore capillary column ( $30 \mathrm{~m} \times 0.545 \mathrm{~mm} \times 3.0 \mu \mathrm{m}, \mathrm{J} \&$ W Scientific Inc., Folsom, CA., USA) was used for separating the chlorinated compounds. The column temperature was maintained at $35^{\circ} \mathrm{C}$ for 1 minute, then programmed to $50^{\circ} \mathrm{C}$ at the rate of $2^{\circ} \mathrm{C} / \mathrm{min}$ and heated to $150^{\circ} \mathrm{C}$ at a rate of $8^{\circ} \mathrm{C} / \mathrm{min}$ with the carrier gas $\left(\mathrm{N}_{2}\right)$ flow rate of $5.6 \mathrm{~mL} / \mathrm{min}$ (linear velocity of $42.3 \mathrm{~cm} / \mathrm{sec}$ ). The standard analytical error was controlled within $5 \%$. The error was determined by calculating the relative standard deviation (RSD) of the peak area of the internal standard and the RSD of the standards of the chlorinated hydrocarbons by performing triplicate tests during the analysis. The detection limits, corresponding to the concentrations in aqueous solution, were $0.10 \mu \mathrm{g} / \mathrm{L}$ for $\mathrm{CT}, 0.60$ $\mu \mathrm{g} / \mathrm{L}$ for $\mathrm{CF}$, and $0.24 \mu \mathrm{g} / \mathrm{L}$ for PCE. The tested bottles were analyzed only once. The $\mathrm{pH}$, oxidationreduction potential (ORP), total organic carbon (TOC) and the microbial activities in the liquid phases were analyzed after headspace analyses .

Oxidation-reduction potential (ORP) and $\mathrm{pH}$ were determined with an Orion EA 920 expandable ion analyzer (Orion Research Inc., Boston., MA., USA) by using an Orion gel-filled combination pH electrode and an Orion model 97-78-00 Pt redox electrode. For ORP measurements, the electrode was calibrated with a ferrous-ferric solution containing $0.1 \mathrm{M}$ ferrous ammonium sulfate $\left(\mathrm{Fe}\left(\mathrm{NH}_{4}\right)_{2}\left(\mathrm{SO}_{4}\right)_{2} \cdot 6 \mathrm{H}_{2} \mathrm{O}\right), 0.1 \mathrm{M}$ ferric ammonium sulfate $\left(\mathrm{Fe}\left(\mathrm{NH}_{4}\right)\left(\mathrm{SO}_{4}\right)_{2} \cdot 12 \mathrm{H}_{2} \mathrm{O}\right)$ and $1.0 \mathrm{M}$ sulfuric acid (Light, 1972). The values were expressed in terms of the oxidation-reduction potential of the sample relative to the $\mathrm{H}_{2} / \mathrm{H}^{+}$and were read out until the potential shift was less than $0.5 \mathrm{mV} / \mathrm{min}$ Total organic carbon (TOC) concentration was obtained by a TOC analyzer (model $700 \mathrm{O}$. I. Corporation, Texas, USA) after filtering the liquid in the test bottle by a $0.2 \mu \mathrm{m}$ cellulose nitrate membrane filter ( $47 \mathrm{~mm}, \mathrm{MFS}$, Dublin, CA., USA).

Enumeration of microbial activities in the solutions in test bottles was determined via an epifluorescence technique, the DAPI method (Coleman, 1980). An epifluorescence microscope equipped with a Nikon mercury lamp supply $\mathrm{HB} 0-100 \mathrm{~W} / 2$ (Nikon, Tokyo, Japan) was used to count the numbers of viable cells of each sample. $10 \mathrm{~mL}$ of the sample were fixed with $0.5 \mathrm{~mL}$ of filtered Formalin (37\% formaldehyde) and was stained with $1 \mathrm{~mL}$ of DAPI solution at the concentration of 0.1 
$\mathrm{mg} / \mathrm{mL}$ (with the final concentration of $0.01 \mathrm{mg} / \mathrm{mL}$ ). Samples were then filtered through $0.2 \mu \mathrm{m}$ cellulose nitrate filters (25mm, Sartorius, Goettingen, Germany), mounted in glycerol and stored in $4^{\circ} \mathrm{C}$ before the microscopic observations.

\section{RESULTS AND DISCUSSION}

Biotransformation in the mixed contaminants system. Figure 1 illustrates the dechlorination of $100 \mu \mathrm{g} / \mathrm{L}$ CT and PCE in the mixed contaminants system. With the acetate concentration of $10 \mathrm{mg} / \mathrm{L}$, nearly complete dechlorination and $48 \%$ of $\mathrm{CT}$ and PCE removal, respectively, were obtained in 56 days. However, an increase in the substrate concentration to $30 \mathrm{mg} / \mathrm{L}$ caused the biotransformation efficiencies of the chlorinated hydrocarbons to be less than those amended with $10 \mathrm{mg} / \mathrm{L}$ of acetate $20 \%$ and $21 \%$ of CT and PCE removals, respectively, were exhibited in 74 days with the redox potentials ranging from $-263 \mathrm{mV}$ to $188 \mathrm{mV}$. Also, the biotransformation of $500 \mu \mathrm{g} / \mathrm{L}$ chlorinated hydrocarbons in the mixed contaminants system demonstrated no obvious transformation in 74 days for the high redox potential system (Figure 2). These results revealed that the redox potential of the environment is a more important environmental factor than the substrate concentration influencing the biotransformation of the chlorinated hydrocarbons. Moreover, high redox potential of microcosms did not provide a sufficient amount of reducing power for chlorinated hydrocarbons, subsequently hampering the dechlorination of chlorinated hydrocarbons.
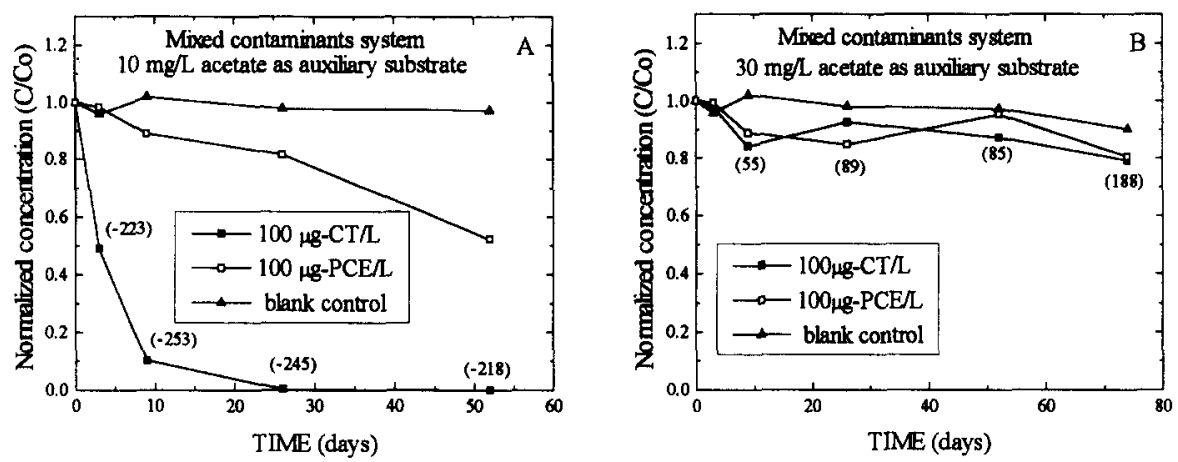

Figure 1. Biotransformation of $100 \mu \mathrm{g} / \mathrm{L} \mathrm{CT}$ and PCE in the mixed contaminants system with the auxiliary substrate concentrations of 10 and $30 \mathrm{mg} / \mathrm{L}$, respectively. The values in the parentheses are the measured redox potentials of the microcosms.

The reason for why an increase of ORP value in microcosms occurs remains unclear. During the experimental period, ferrous sulfide, functioning as the reservoir of reducing power, was produced when $\mathrm{Fe}^{2+}$ and $\mathrm{S}^{2-}$ were simultaneously added into the microcosms. However, precipitation of ferric hydroxide was observed with time, inferring that a trace amount of oxidizing agents may be present in the anaerobic media and would react slowly with FeS. The redox reaction occurring in the microcosms is yet another possibility. Matheson and Tratnyek(1994) observed that the ORP values of the system 
increased from $-300 \mathrm{mV}$ to $100 \mathrm{mV}$ when $\mathrm{CT}$ was introduced into the $\mathrm{Fe}^{0} / \mathrm{Fe}^{2+}$ reaction controlled microcosms. In this study, the slow reaction of $\mathrm{FeS}$ and oxidizing agent introduced through feeding materials did not provide a sufficient amount of reducing power for dechlorination, thereby causing the increase of ORP.
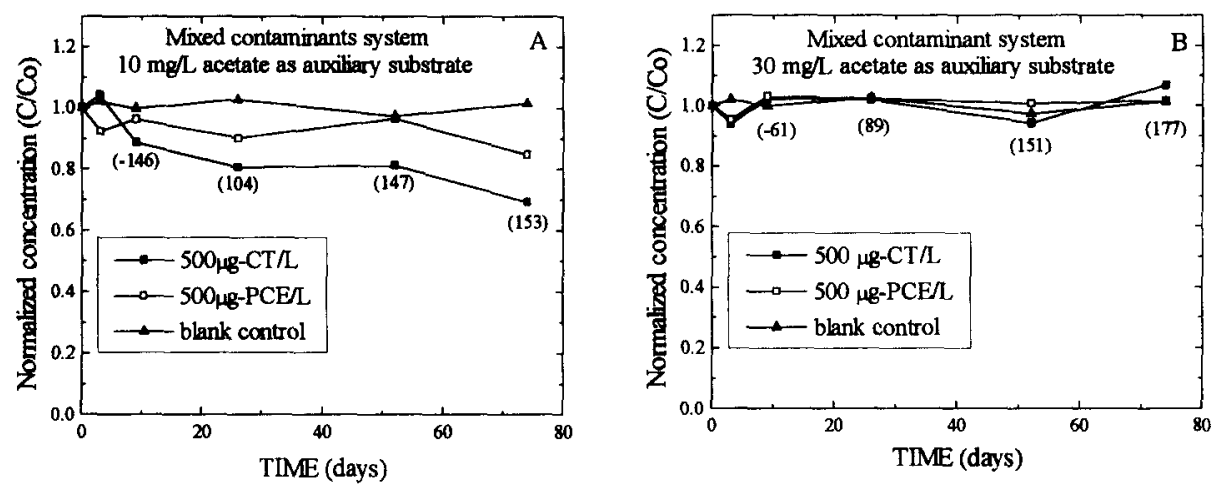

Figure 2. Biotransformation of $500 \mu \mathrm{g} / \mathrm{L} \mathrm{CT}$ and PCE in the mixed contaminants system with the auxiliary substrate concentrations of 10 and $30 \mathrm{mg} / \mathrm{L}$, respectively. The values in the parentheses are the measured redox potentials of the microcosms.

Biotransformations in the single contaminant system. The biotransformations of $100 \mu \mathrm{g} / \mathrm{L}$ chlorinated hydrocarbons in the single contaminant system with 10 and $30 \mathrm{mg} / \mathrm{L}$ of acetate are depicted in Figure 3 . Removal of $39 \%$ of the original CT input was exhibited in 74 days for bottles amended with $10 \mathrm{mg} / \mathrm{L}$ of acetate. Whereas $42 \%$ of CT removal was reached when $30 \mathrm{mg} / \mathrm{L}$ of acetate was amended into the microcosm. The measured redox potentials of the cultures were -263 to $69 \mathrm{mV}$ and -263 to $-68 \mathrm{mV}$ for batches amended with 10 and $30 \mathrm{mg} / \mathrm{L}$ substrate, respectively. For PCE, only slight degradation in the microcosms with $10 \mathrm{mg} / \mathrm{L}$ acetate was observed as compared with the blank controls. The redox potentials in the environments ranged between -263 and $-52 \mathrm{mV}$ in 56 days and rose to $159 \mathrm{mV}$ on the 74th day. Furthermore, increasing the substrate concentration to $30 \mathrm{mg} / \mathrm{L}$ would cause removal of 62 $\%$ of the original PCE input with the redox potentials ranging from -263 to $-58 \mathrm{mV}$.

The biotransformations of $500 \mu \mathrm{g} / \mathrm{L}$ of chlorinated hydrocarbons in the single contaminant system with 10 and $30 \mathrm{mg} / \mathrm{L}$ of acetate are shown in Figure 4, respectively. The bottles amended with 10 and 30 $\mathrm{mg} / \mathrm{L}$ supplemental substrate exhibited $42 \%$ and $47 \%$ of PCE removal, respectively, in 108 days. The redox potential of the bottles were similar, i.e., ranging from -263 to $-119 \mathrm{mV}$, indicating that the anaerobic consortia could transform PCE when the redox potential is lower than $-119 \mathrm{mV}$. For CT, disappearances of $29 \%$ and $58 \%$ were demonstrated in 108 days and the values of the redox potentials of the bottles were below -84 and $-74 \mathrm{mV}$ for bottles with 10 and $30 \mathrm{mg} / \mathrm{L}$ supplemental substrate, respectively. 

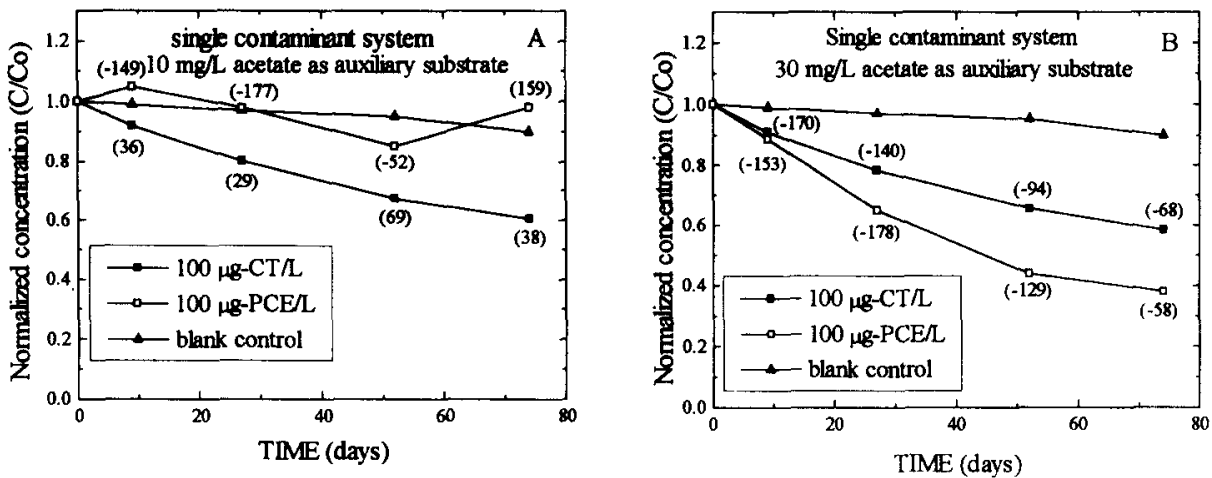

Figure 3. Biotransformation of $100 \mu \mathrm{g} / \mathrm{L} \mathrm{CT}$ and PCE in the single contaminant system with the auxiliary substrate concentrations of 10 and $30 \mathrm{mg} / \mathrm{L}$, respectively. The values in the parentheses are the measured redox potentials of the microcosms.

The redox potentials of the single contaminant system with $500 \mu \mathrm{g} / \mathrm{L}$ of CT were similar within 108 days $(-263 \mathrm{mV}$ to $-80 \mathrm{mV})$. Whereas different removal efficiencies of $\mathrm{CT}$ were obtained. This result depicts that the substrate concentration could change the microbial dechlorinating capability when ORP value of the microcosm was below some threshold value. Recent researches have addressed the potential role of supplemental sources on the biotransformation of chlorinated compounds (Nies and Vogel, 1990; DiStefano et al., 1992; Doong and Wu, 1995; Picardal et al., 1995). A higher concentration of auxiliary substrate provided a higher intensity of electron activities for microbial communities to undergo the dechlorination reactions, thereby causing a corresponding increase of the biotransformation efficiency when the environment has an adequate reducing potential (low redox potential )
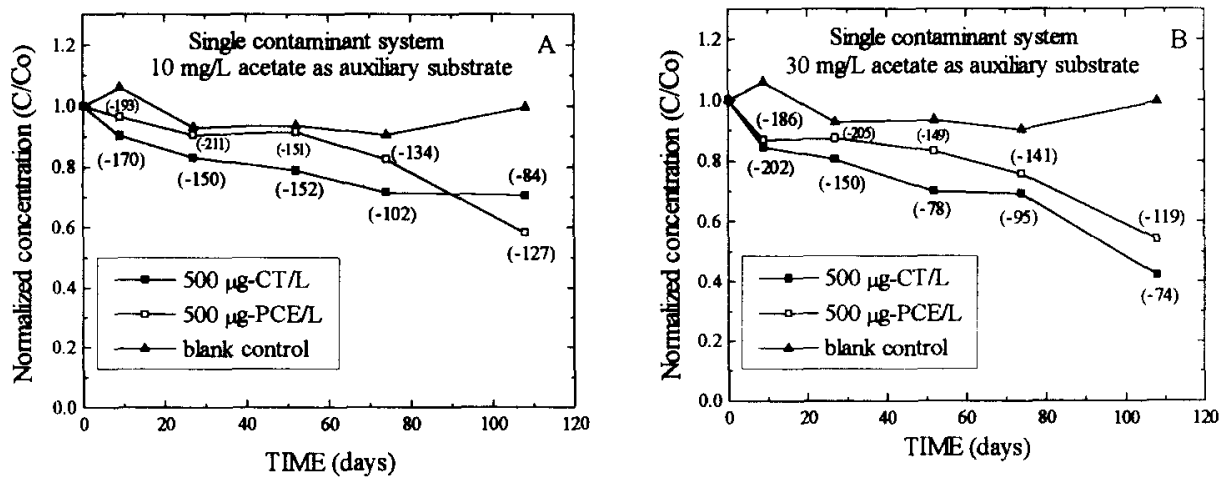

Figure 4. Biotransformation of $500 \mu \mathrm{g} / \mathrm{L} \mathrm{CT}$ and PCE in the single contaminant system with the auxiliary substrate concentrations of 10 and $30 \mathrm{mg} / \mathrm{L}$, respectively. The values in the parentheses are the measured redox potentials of the microcosms. 
Low redox potential of the environment is the driving force for the onset of reductive dechlorination of chlorinated hydrocarbons. Also, the threshold value influencing the biotransformation of chlorinated hydrocarbons may exist, although the particular reaction mechanism remains unclear. Parsons and Large (1985) used an ORP electrode to measure the redox potential of the experimental static microcosm, indicating that TCA, CT, and PCE could be degraded when the ORP values of the microcosms were -150 to $80 \mathrm{mV},-100$ to $65 \mathrm{mV}$, and -40 to $60 \mathrm{mV}$, respectively. Hrubec et al. (1986) demonstrated that the concentrations of CT, TCA, and PCE decreased when the ORP value of the environment was about $100 \mathrm{mV}$. A less pronounced effect was also observed when the ORP value of the environment was about $200 \mathrm{mV}$. Furthermore, Kastner (1991) suggested that the redox potential of 0 to $-150 \mathrm{mV}$ is necessary for the complete transformation of PCE to cis-dichloroethylene (c-DCE). A sufficient correlation between the logarithm of the pseudo-first-order rate constants and the standard reduction potentials of the polychlorinated hydrocarbons was also well documented (Gantzer and Wackett, 1991; Assaf-Anid et al., 1994). In this study, removals of $30 \%$ to $99.9 \%$ and $42 \%$ to $62 \%$ for CT and PCE were observed when the redox potential were -263 to $69 \mathrm{mV}$ and -263 to $-58 \mathrm{mV}$, respectively. Whereas only $20 \%$ to $29 \%$ and about $20 \%$ of CT and PCE removals were reached when the redox potentials were -263 to $188 \mathrm{mV}$. Figure 5 illustrates the relationship between the redox potential of the environment and the extent of the biotransformation of CT and PCE. The redox potentials of the environment lower than 70 and $-60 \mathrm{mV}$ seem to be necessary for the obvious dechlorination (> 30\%) of CT and PCE, respectively.
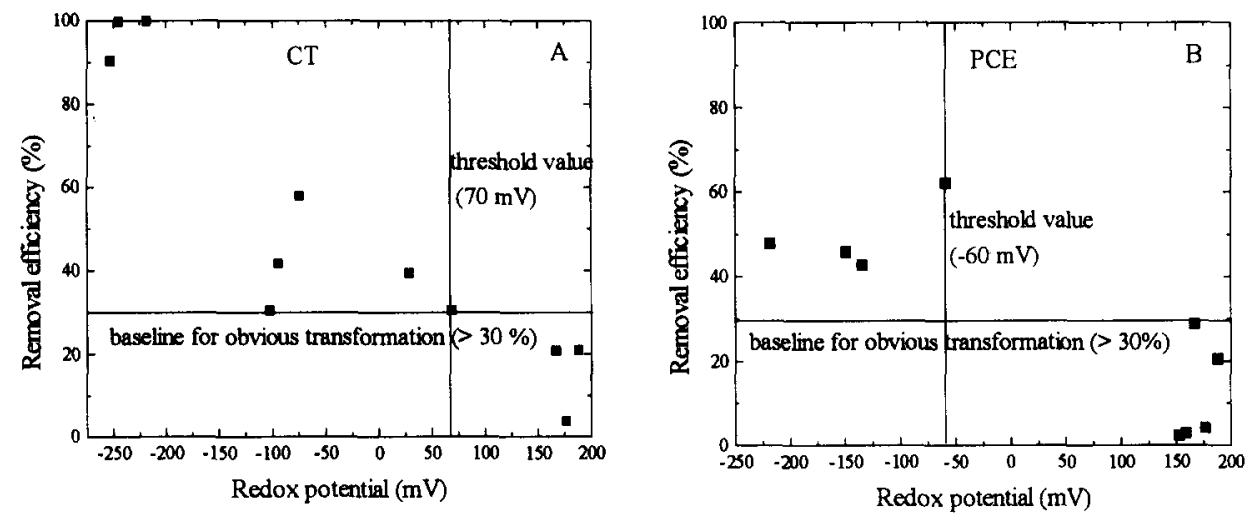

Figure 5. The threshold values of redox potential of CT and PCE for obvious transformation $(>30 \%)$.

Microbial activities and TOC concentrations. The microbial activities of the liquid phases of the microcosms in the single and mixed contaminant(s) systems are illustrated in Figure 6. Three- to 10folds increase of biomass was obtained within 74 days. Whereas only 2- to 7-folds were demonstrated within 108 days, implying that microbial mass decreased with time. Also, the bottles with $30 \mathrm{mg} / \mathrm{L}$ supplemental substrate produced a more bright blue dot than those with $10 \mathrm{mg} / \mathrm{L}$ supplemental substrate through the microscopic observation. When the bottles were amended with $100 \mu \mathrm{g} / \mathrm{L}$ of chlorinated hydrocarbons, the TOC concentrations in microcosms, as summarized in Table 2 , 
decreased from 9.8 to $4.8 \mathrm{mg} / \mathrm{L}$ (average value) and from 19.3 to $4.1 \mathrm{mg} / \mathrm{L}$ (average value) for the substrate concentration of 10 and $30 \mathrm{mg} / \mathrm{L}$, respectively. Similar results were also obtained for bottles with $500 \mu \mathrm{g} / \mathrm{L}$ of chlorinated hydrocarbons. The TOC concentration were decreased from 10.1 to 3.9 $\mathrm{mg} / \mathrm{L}$ (average value) and from 20.7 to $4.0 \mathrm{mg} / \mathrm{L}$ (average value) for the substrate concentration of 10 and $30 \mathrm{mg} / \mathrm{L}$, respectively. These results demonstrate that the supplemental substrate depleted rapidly and served as carbon and energy sources to sustain the microbial dechlorinating capability. The residual dissolved organic carbon (DOC) $(3.9 \sim 4.8 \mathrm{mg} / \mathrm{L})$ may be due to the organic matters excreted by bacteria or the cell components from lyzed cells which are refractory for microbial decomposition.

Table 2. The TOC concentrations in liquid phases of the microcosms

\begin{tabular}{|c|c|c|c|c|c|c|}
\hline \multicolumn{2}{|c|}{$\begin{array}{l}\text { Chlorinated } \\
\text { Hydrocarbons }\end{array}$} & \multirow{3}{*}{$\begin{array}{l}\text { Time } \\
\text { (days) }\end{array}$} & \multicolumn{4}{|c|}{ TOC (mg/L) } \\
\hline \multirow[b]{2}{*}{$(\mathrm{mg} / \mathrm{L})$} & \multirow{2}{*}{ type } & & \multicolumn{2}{|c|}{ mixed contaminants system } & \multicolumn{2}{|c|}{ single contaminant system } \\
\hline & & & $10 \mathrm{mg} / \mathrm{L}^{*}$ & $30 \mathrm{mg} / \mathrm{L}$ & $10 \mathrm{mg} / \mathrm{L}$ & $30 \mathrm{mg} / \mathrm{L}$ \\
\hline \multirow[t]{12}{*}{100} & PCE & 0 & 9.77 & 19.30 & 9.77 & 19.30 \\
\hline & & 3 & - & 9.86 & - & - \\
\hline & & 11 & 8.42 & 6.46 & 5.25 & 5.87 \\
\hline & & 26 & 5.34 & 4.20 & 4.62 & 6.79 \\
\hline & & 52 & 4.90 & 3.10 & 5.42 & 3.07 \\
\hline & & 74 & 4.19 & 4.01 & 5.17 & 4.01 \\
\hline & $\mathrm{CT}$ & 0 & 9.77 & 19.30 & 9.77 & 19.30 \\
\hline & & 3 & - & 9.86 & - & 11.79 \\
\hline & & 11 & 8.42 & 6.46 & 6.24 & 6.34 \\
\hline & & 26 & 5.34 & 4.20 & 5.83 & 5.16 \\
\hline & & 52 & 4.90 & 3.10 & 3.50 & 3.29 \\
\hline & & 74 & 4.19 & 4.01 & 4.72 & - \\
\hline \multirow[t]{12}{*}{500} & PCE & 0 & 10.13 & 20.68 & 10.13 & 20.68 \\
\hline & & 11 & 5.55 & 5.33 & 6.22 & 6.10 \\
\hline & & 26 & 4.24 & 4.45 & 5.18 & 5.17 \\
\hline & & 52 & 2.96 & 3.01 & 3.17 & 4.66 \\
\hline & & 74 & 4.62 & 3.47 & 5.01 & 4.81 \\
\hline & & 108 & 4.24 & 4.66 & 3.34 & 3.27 \\
\hline & $\mathrm{CT}$ & 0 & 10.13 & 20.68 & 10.13 & 20.68 \\
\hline & & 3 & 8.68 & 9.49 & 8.19 & 9.91 \\
\hline & & 11 & 5.55 & 5.33 & 5.50 & 6.07 \\
\hline & & 26 & 4.24 & 4.45 & 5.58 & 5.61 \\
\hline & & 52 & 2.96 & 3.01 & 3.31 & 3.61 \\
\hline & & 74 & 4.62 & 3.47 & 4.20 & 4.17 \\
\hline
\end{tabular}

* : concentration of supplemental substrate applied into the microcosm

_ : no data determined. 

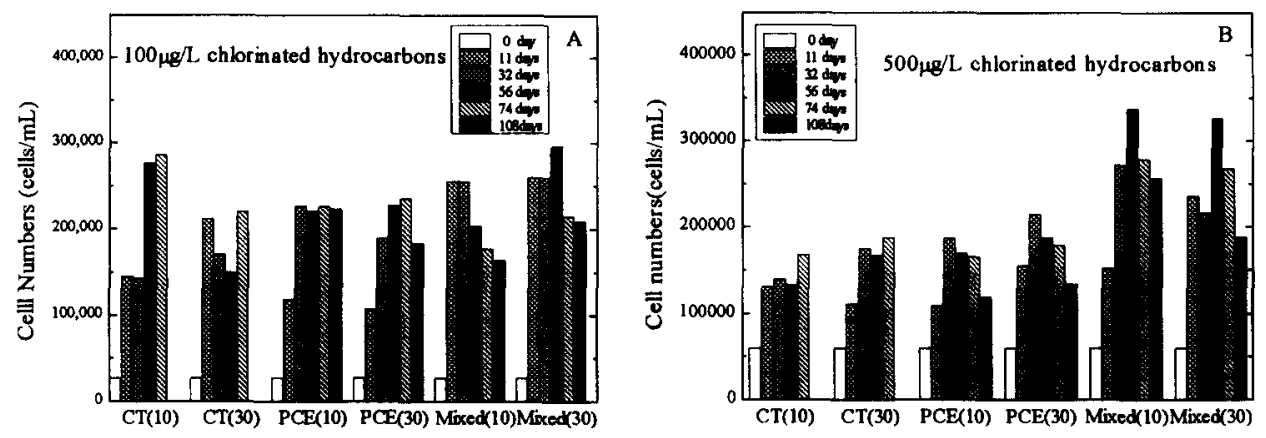

Figure 6. The microbial activities in the liquid phases of the microcosms in the single and mixed contaminant(s) systems. The values in the parentheses are the concentrations of the auxiliary substrate.

The fluorescing stain, DAPI, is a highly specific stain for DNA and produces a blue bright light when excited with UV light. Though the microbial mass increased concomitantly with the increasing concentration of the auxiliary substrate, no correlation was found between the DAPI counts and the biotransformation rate of chlorinated hydrocarbons, demonstrating that DNA content of microorganisms is not an appropriate biochemical index for the dechlorination of chlorinated hydrocarbons. Kastner (1991) observed that the number of cells in dechlorinating cultures decreased during dechlorination, implying that the cells in the latter period of their lives might support the dechlorination even better. Some microbial transition-metal containing coenzymes, such as vitamin $\mathrm{B}_{12}(\mathrm{Co})$, coenzyme $\mathrm{F} 430(\mathrm{Ni})$, and hematin $(\mathrm{Fe})$, were also demonstrated to enhance the dechlorination capabilities of the microbial strains to degrade the polychlorinated ethylene and chlorinated aromatics (Gantzer and Wackett, 1991; Schanke and Wackett, 1992; Assaf-Anid et al., 1994). These observations depicted that certain redox-active coenzymes in the microbial metabolic pathways, such as coenzyme $\mathrm{F}_{430}$ and vitamin $\mathrm{B}_{12}$, may be better biochemical indices for the status of the reductive dechlorination reactions.

\section{CONCLUSIONS}

This study has demonstrated that the redox potential of the environment is a more influential environmental factor than the substrate concentration for the biotransformation of chlorinated hydrocarbons. The microcosms with a lower redox potential provides electrons with a higher potential for chlorinate hydrocarbons and catalyzes the biotransformation more readily. Disappearances from $22 \%$ to $99.9 \%$ and $20 \%$ to $62 \%$ of CT and PCE, respectively, were demonstrated, depending on the redox condition of the environment. However, no significant biotransformation of TCA was observed in 74 days. This result can be accounted for by the strong-electron-acceptor inhibition hypothesis 
which is based on the thermodynamic rules. The chlorinated hydrocarbons can function as electron acceptors under denitrification, sulfate-reducing, and methanogenic conditions for their high standard half redox potential. Under low redox potential conditions, the chlorinated hydrocarbons successfully capture electrons in the system and, therefore, facilitate the dechlorination of themselves more readily

Some threshold values of redox potentials controlling the onset of dechlorination of chlorinated hydrocarbons exist. Complete dechlorination of CT was demonstrated when the redox potential was lower than $-220 \mathrm{mV}$. In addition, the values of 70 and $-60 \mathrm{mV}$ seemed to be necessary for the obvious transformation of CT and PCE, respectively. The effects of substrate concentration were also evident when the redox potential of the environment dipped below the threshold value. Also, the microbial activity increased with an increase of the auxiliary substrate concentration; however, no positive correlation was found between the removal efficiency and the microbial mass. This study highlights the effects of the redox potential and the substrate concentration on the biotransformation of chlorinated hydrocarbons. Nevertheless, the biotransformed products have not been identified. Further investigation concerning the identification of the biotransformed products under different redox potentials will be conducive to elucidating the particular dechlorination reaction mechanisms of the chlorinated hydrocarbons.

\section{ACKNOWLEDGEMENTS}

The authors would like to thank the National Science Council, R. O. C. for financial support of this manuscript under Contract No. NSC 80-0421-E002-09Z.

\section{REFERENCES}

Anderson, T. A., Guthrie, E. A. and Walton, B. T., Environ. Sci. Technol. 1993, 27, 2630.

Assaf-Anid, N., Hayes, K. F. and Vogel, T. M., Environ. Sci. Technol., 1994, $28,246$.

Bagley, D. M. and Gossett, J. M., Appl. Environ. Microbiol., 1990, 56, 2511.

Bouwer, E. J., and Wright, J. P., J. Contam. Hydrol., 1988, 2, 155.

Cobb, G. D. and Bouwer, E. J., Environ. Sci. Technol., 1991, 25, 1068.

Coleman, A. W., Limnol. Oceanogr., 1980, 25, 948.

Criddle, C. S., DeWitt, J. T., and McCarty, P. L., Appl. Environ. Microbiol., 1990, 56, 3247

Criddle, C. S. and McCarty, P. L., Environ. Sci. Technol, 1991, 25, 973.

DeBruin, W. P., Kotterman, M. J. J., Posthumus, M. A., Schraa, G. and Zehnder, A. J. B., Appl. Environ. Microbiol, 1992, 58,1996.

Dybas, M. J, Tarata, G. M., and Criddle, C. S., Appl. Environ. Microbiol., 1995, 61, 758.

DiStefano, T. D., Gossett, J. M. and Zinder, S. H., Appl. Environ. Microbiol., 1992, 58, 3622.

Doong, R. A., and Wu, S. C., Chemosphere, 1995a, 30, 1499.

Doong, R. A., and Wu, S. C., Wat. Environ. Res., 1995b. 67, 276. 
Egli, C., Tschan, T., Scholtz, R., Cook, A. M. and Leisinger, T., Appl. Environ. Microbiol., 1988, 54, 2819.

Esaac, E. G. and Matsumur, F., Pharmac. Ther., 1980, 9, 1-26.

Fan, S. and Scow, K. M., Appl. Environ. Microbiol., 1993, 59, 1911.

Federal Register, Fed. Regist., 1989, 54, 22062.

Gantzer, C. J. and Wackett, L. P., Environ. Sci. Technol., 1991, 25, 715

Gibson, S. A. and Sewell, G. W., Appl. Environ. Microbiol., 1992, 58, 1392.

Grundl, T. J. and Macalady, D. L., J. Contam. Hydrol., 1989, 5, 97

Hopkins, G. D., Semprini, L. and McCarty, P. L., Appl. Environ. Microbiol., 1993, 59, 2277.

Hrubec, J., Luijten, J. A., Luijten, W. C. M. M. and Piet, G. J., Wat. Res., 1986, 20, 1119.

Kastner, M., Appl. Environ. Microbiol., 1991, 57, 2039.

Light, T. S., Anal. Chem., 1972, 44, 1038

Matheson, L. J., and Tratnyek, P. G., Environ. Sci. Technol., 1994, 28, 2045

Nies, L. and Vogel, T. M., Appl. Environ. Microbiol., 1990, 56, 2612.

Owen, W. F., Stuckey, D. C., Healy, J. B. Jr., Young, L. Y., and McCarty, P. L., Wat. Res., 1979, 13, 485.

Parsons, F. and Barrio-Lage, G. B., J. Am. Water Works Assoc., 1985, 77, 52.

Parsons, F., Barrio-Lage, G. B. and Rice, R., Environ. Toxicol. Chem., 1985, 4, 379.

Peiffer, S., Klemm, O., Pecher, K. and Hollerung, R., J. Contam. Hydrol., 1992, 10, 1.

Picardal, F., Arnold, R. G. and Huey, B. B., Appl. Environ. Microbiol., 1995, 61, 8

Rainwater, K., Mayfield, M. P., Heintz, C. and Claborn, B. J., Wat. Environ. Res. 1993, 65, 717.

Roberts, P. V., Schreiner, J. and Hopkins, G. D., Wat. Res., 1982, 16, 1025.

Schanke, C. A. and Wackett, L. P., Environ. Sci. Technol, 1992, 26, 830.

Semprini, L. and McCarty, P. L., Ground Water, 1992, 30, 37.

Semprini, L., Hopkins, G. D., McCarty, P. L. and Roberts, P. V., Environ. Sci. Technol., 1992, 26, 2454.

Tatara, G. M., Dybas, M. J. and Criddle, C. S., Appl. Environ. Microbiol., 1993, 59, 2126.

Vogel, T. M., Criddle, C. S. and McCarty, P. L., Environ. Sci. Technol.1987, 21, 722. 